This is an Open Access version of the article: Nosrati $\mathrm{K}$, Govers $\mathrm{G}$, Ahmadi $\mathrm{H}$, Sharif $\mathrm{F}$,

Amoozegar MA, Merckx R, Vanmaercke M (2011) An exploratory study on the use of enzyme activities as sediment tracers: biochemical fingerprints? International Journal of Sediment Research 26: 136-151.

\title{
An exploratory study on the use of enzyme activities as sediment tracers: biochemical fingerprints?
}

\author{
Kazem NOSRATI ${ }^{1}$, Gerard GOVERS ${ }^{2}$, Hassan AHMADI ${ }^{3}$, Forood SHARIFI ${ }^{4}$, Mohammad Ali \\ AMOOZEGAR ${ }^{5}$, Roel MERCKX $X^{6}$, and Matthias VANMAERCKE ${ }^{7}$
}

\footnotetext{
${ }^{1}$ Assis. Prof., Department of Physical Geography, Faculty of Earth Sciences, Shahid Beheshti University, 1983963113 Tehran, Iran, Corresponding author. Tel.: +98 21 29902602; Fax: +98 21 29902628. E-mail: k_nosrati@sbu.ac.ir (K. Nosrati).

${ }^{2}$ Full Prof., Division of Geography, Department of Earth and Environmental Sciences, K.U. Leuven, Celestijnenlaan 200E, 3001 Leuven, Belgium

${ }^{3}$ Full Prof., Faculty of Natural Resources, University of Tehran, Karaj, Iran

${ }^{4}$ Assis. Prof., Forest, Range and Watershed Management Organization, Tehran, Iran

${ }^{5}$ Associate Professor, Faculty of Biology, College of Sciences, University of Tehran, Tehran, Iran

${ }^{6}$ Full Prof., Division of Soil and Water Management, Department of Earth and Environmental Sciences, K.U. Leuven, Kasteelpark Arenberg 20, 3001 Leuven, Belgium

${ }^{7}$ Ph.D. candidate, Division of Geography, Department of Earth and Environmental Sciences, K.U. Leuven, Celestijnenlaan 200E, 3001 Leuven, Belgium
}

\begin{abstract}
Little information exists on the potential of soil enzyme activities, which are sensitive to soil properties and management, for the characterization of sediment sources at the catchment scale. The objective of this study is to explore and evaluate enzyme activity as tracer for sediment fingerprinting in the Hiv catchment (55 km2), Iran. Therefore, four enzymes were measured from 42 different sampling sites, covering three sediment source areas (rangeland/surface erosion, orchard/surface erosion, and streambank erosion), as well as from 12 sediment samples from reservoir check dams (sediment sinks). The results indicate that, based upon backward mode discriminant analysis, $\beta$ glucosidase and dehydrogenase, allowed more than $95 \%$ of the samples to be correctly assigned to their source areas. These enzymes were selected as input data for a mixing-model to determine the relative contribution of the sampled sediment sources. The mean contributions from rangeland, orchard and streambank sources in the study area were estimated as $11.3 \%, 15.1 \%$ and $73.7 \%$, respectively. Using geochemical tracers, the mean contribution from rangeland, orchard and streambank sources was estimated as $14.1 \%, 9.5 \%$ and $74.8 \%$, respectively. Combined biochemical and geochemical tracers, similar values were obtained (18.7\%, $10.7 \%$ and $70.7 \%$, respectively). Our results indicate that soil enzyme activity allows for a good characterization of sediment sources, and can provide a complementary tool to currently existing sediment fingerprinting approaches. However, the method should be also tested in other regions.
\end{abstract}

Key Words: Sediment source, Enzyme activity, Biochemical fingerprints, Mixing model, Hiv Catchment 


\section{Introduction}

Soil erosion causes environmental degradation problems such as soil and water resources degradation, reduction of soil fertility, destruction of range and agricultural lands, desertification, recurring floods, sedimentation of reservoirs, and pollution of fishery habitats (Yi et al., 2008). Semi-arid regions may suffer dramatic increases in erosion due to increasing population pressure and the extension of poor agricultural practices to steeplands. Available information suggests that the severity of soil erosion in Iran has strongly increased over the last 50-60 years. Average soil erosion in Iran in 1951, 1961, 1981, 1993, 1999 and 2002 was estimated to be ca. 3.0, 4.6, 9.1, 15.2, 21.2 and 24.3 tons ha-1 year-1, respectively, which would correspond to an increase of $800 \%$ in soil erosion between 1951 and 2002 (Nosrati et al., 2011). Although these numbers are highly uncertain, they confirm that soil erosion is now clearly an important environmental problem in Iran.

Knowledge of rates of soil loss and sedimentation, derived from different sources (land use and erosion types), is required for the evaluation of erosion models. It is also critical for identifying the watershed activities that have the greatest impact on the water quality, allowing improvement of management practices to minimize the off-site effects of erosion and sedimentation. Therefore, there is a strong need for techniques to establish an accurate sediment budget and predict catchment sediment yield in an efficient and cost-effective manner (Walling et al., 2003).

The concept of fingerprinting refers to a field based measurement technique that apportions or unmixes eroded soils into multiple sources soil through the use of tracers (Collins et al., 1998). A wide range of soil chemical and physical properties, such as geochemical properties (Collins et al., 1997; Juracek and Ziegler, 2009), biogeochemical tracers (Fox and Papanicolaou, 2008) mineral magnetic properties (Hatfield and Maher, 2009), radionuclides concentration (Estrany et al., 2010; Smith and Dragovich, 2008), infrared spectroscopy (Poulenard et al., 2009), and rare earth elements (Zhang et al., 2008) have been used as sediment tracers.

An effective tracer should be able to differentiate between potential sediment sources and display conservative behavior during erosion and fluvial transport (Foster and Walling, 1994). However, the ability of a tracer to distinguish sediment sources depends on the nature of the catchment: sediment sources need to be sufficiently different with respect to the tracers used in order to allow for discrimination (Rowan et al., 2000).

Many soil functions that are related to microbial activity and diversity are closely related to enzyme activities (Zornoza et al., 2007). It is therefore not surprising that changes in soil enzyme activities have been suggested as indicators of changes or disturbances of the soil ecosystem (Naseby and Lynch, 2002).

Soil biochemical indicators provide a means for assessing the degree of soil degradation because they act as early and sensitive indicators of soil ecological stress (Chaer et al., 2009). Soil enzymes are inherently more sensitive to environmental conditions than mineral soil properties and therefore reflect the interaction between natural biochemical processes and anthropogenic management practices within 
a catchment. Therefore, enzymes may also be used as biochemical indices to discriminate sediment sources.

Acosta-Martinez and Zobeck (2004) studied the potential of three enzyme activities ( $\beta$-glucosidase, alkaline phosphatase, and arylsulfatase) to discriminate wind soil erosion sources and concluded that enzyme activity allowed to identify the soil source of the dust samples.

The usability of enzymes as tracers crucially depends on their stability. Some enzyme activities do not show seasonal variation, probably because most of the activity is associated with enzymes stabilized by soil colloids (Nannipieri et al., 2002; Tate, 2002). Enzymes are reported to be stable for many months and even years in air-dried soils (Tabatabai and Dick, 2002). Also the assays of soil enzymes are generally simple, accurate, sensitive, and relatively rapid (Nannipieri et al., 2002). Consequently, sediment fingerprinting using enzymes could be complementary tool to currently existing fingerprinting techniques as they may allow to identify the contributions of different sediment sources that are otherwise very similar in composition. The objective of this study was therefore to explore and evaluate the potential of soil enzyme activities as tracers for sediment source fingerprinting in a semiarid mountainous area in Iran by comparing the results of enzyme analysis to that of a classical geochemical fingerprinting approach.

\section{Materials and methods}

\subsection{Study area}

The study was conducted in the Hiv catchment $\left(35^{\circ} 59^{\prime}\right.$ to $36^{\circ} 07^{\prime} \mathrm{N}$ and $50^{\circ} 36^{\prime}$ to $\left.50^{\circ} 43^{\prime} \mathrm{E}\right)$ which is part of the Hashtgerd Drainage Basin, in the Southern Alborz Mountains, 70 km Northwest of Tehran, Iran (Fig. 1). The drainage area of the Hiv catchment is $55 \mathrm{~km} 2$ including 400 ha (7.3\%) of orchards (walnut, almond and cherry trees), 128 ha (2.3\% of total area) of residential rural area, 4322 ha (78.6\% of total area) rangelands, and 650 ha (11.8\% of total area) of rock outcrops. The catchment has variable lithological characteristics, with outcrops of Pre-Cambrian to Quaternary Formations (Fig. 1). The Hiv catchment has a mountaineous topography, with a minimum and maximum height $1,280 \mathrm{~m}$ and 2,720 $\mathrm{m}$ above sea level respectively. The average slope gradient is $27 \%$. The soils within the catchment are mainly Typic Xerorthents and Typic Calcixerepts. A dispersed topsoil sample may contain 16 to $84 \%$ sand, 9 to 57\% silt, and 7 to 35\% of clay (Nosrati, 2010). Long-term (1975-2003) mean annual precipitation in the study area is ca. $445 \mathrm{~mm}$.

Throughout Iran and particularly in semi-arid areas where the effects of erosion are considerable, the construction of check dams is widespread. In the drainage network of the study area, some concrete and cement check dams are present in streams and channels. These check-dams are small barriers (in general less than $5 \mathrm{~m}$ high) built across the direction of water flow on shallow rivers and streams for the purpose of sediment retention and erosion reduction.

\subsection{Sampling and data collection}


Potential sediment sources were classified in three main groups; rangeland/surface erosion, orchard/surface erosion and streambank erosion. 42 representative samples were collected from these potential sources at different locations within the study catchment (Fig. 1).

The samples were collected by taking a representative sample of the upper layer of the source material $(0-5 \mathrm{~cm})$ using a trowel. In the orchards and on the rangeland 5 sub-samples were collected over an area of approximately $100 \mathrm{~m} 2$ which were mixed into a single composite sample. On the channel banks, 5 subsamples were collected with $20 \mathrm{~m}$ from each other. Furthermore, 12 sediment samples were collected from fresh surface dam reservoirs deposits. In reservoirs with a large $(>0.5 \mathrm{~m})$ water depth samples were collected using a $0.02 \mathrm{~m}^{2}$ Petit-Ponar grab sampler, while a trowel was used when water depth was low. At each sampling location 7 small (500 g) samples of deposited sediment were collected and homogeneously mixed. Once collected, whenever necessary, the soil and sediment samples were gently air-dried to the point of soil moisture suitable for sieving. In order to remove bias associated with grainsize effects, only the $<63 \mu \mathrm{m}$ soil and sediment fraction was used for enzyme activity and geochemical analysis (Collins et al., 1997). After sieving, the samples were temporarily conserved in sealed plastic bags and were stored in a field refrigerator on ice and transported to the laboratory. The samples for enzyme activity analysis were kept field moist and stored frozen until analysis. In the laboratory, grain size composition was measured after adding $\mathrm{H} 2 \mathrm{O} 2$ and (NaPO3)6 as dispersants.

\subsection{Enzyme activities}

Four enzyme activities (urease, alkaline phosphatase, $\beta$-glucosidase and dehydrogenase) were measured in the sediment and sediment source samples. For the determination of urease activity, $5 \mathrm{~g}$ of the soil was incubated with $2.5 \mathrm{ml}$ of a urea solution and $20 \mathrm{ml}$ borate buffer for $2 \mathrm{~h}$ at $37^{\circ} \mathrm{C}$. After the incubation, released ammonium was extracted with $50 \mathrm{ml}$ of $\mathrm{KCl}$ solution. The solution was filtered and $9 \mathrm{ml}$ of distilled water, $5 \mathrm{ml}$ of Na-salicylate/ $\mathrm{NaOH}$ solution and $2 \mathrm{ml}$ of Na-dichloroisocyanurate solution were added to $1 \mathrm{ml}$ of the clear solution. Blanks were performed by adding the urea at the end of incubation. The ammonium was determined by absorption on a spectrophotometer (Shimadzu UV160A) at a wavelength of $690 \mathrm{~nm}$ (Kandeler and Gerber, 1988; Alef and Nannipieri, 1995).

Soil alkaline phosphatase and $\beta$-glucosidase activity were determined using p-nitrophenylphosphate (PNPP, 0.05M) and p-nitrophenyl- $\beta$-D-glucopyranoside (PNG, 0.05M) as substrates, respectively (Tabatbai, 1994). These assays were based on the release and detection of p-nitrophenol (PNP). $1 \mathrm{~g}$ of soil was incubated with $4 \mathrm{ml}$ of modified universal buffer (MUB, $\mathrm{pH}=6$ for $\beta$-glucosidase and $\mathrm{pH}=11$ for alkaline phosphatase) together with $1 \mathrm{ml}$ substrates for 1 hour at $37^{\circ} \mathrm{C}$. After incubation, the reaction was stopped and the yellow color from the p-nitrophenol was developed by the addition of 1 $\mathrm{ml} 0.5 \mathrm{M} \mathrm{CaCl} 2$ and $4 \mathrm{ml}$ of $0.1 \mathrm{M}$ THAM buffer ( $\mathrm{pH} 12$ ) for $\beta$-glucosidase, and $1 \mathrm{ml} 0.5 \mathrm{M} \mathrm{CaCl} 2$ and $4 \mathrm{ml}$ of $0.5 \mathrm{M} \mathrm{NaOH}$ for alkaline phosphatase. The solution was mixed and filtered (Whatman No. 42). Controls were performed by adding the substrate after the reaction was stopped. PNP activity was 
measured by absorption in a spectrophotometer (Shimadzu UV-160A) at a wavelength of 400-420 nm and quantified by comparison with a standard curve (Tabatabai, 1994; Acosta-Martinez and Zobeck, 2004; Chaer et al.,2009).

For the determination of dehydrogenase activity, $20 \mathrm{~g}$ of soil samples were mixed with $0.2 \mathrm{~g} \mathrm{CaCO} 3$ and 3 replicates of $6 \mathrm{~g}$ of mixed soil were incubated for $24 \mathrm{~h}$ at $37^{\circ} \mathrm{C}$ with $1 \mathrm{ml}$ substrate of $3 \%$ 2,3,5triphenyltetrazolium chloride (TTC) and $2.5 \mathrm{ml}$ of distilled water. After incubation, $10 \mathrm{ml}$ methanol was added, then filtered and diluted the filtrate to $100 \mathrm{ml}$ volume with methanol. The amount of triphenyl formazan (TPF) was measured by absorption on a spectrophotometer (Shimadzu UV-160A) at a wavelength of $485 \mathrm{~nm}$ with methanol as a blank and calculated with a reference calibration graph prepared from a TPF standard (Tabatabai, 1994). The results of enzyme activities were reported on an oven dry-weight basis, determined by drying the soils for $24 \mathrm{~h}$ at $105^{\circ} \mathrm{C}$.

\subsection{Geochemical analysis}

$3 \mathrm{~g}$ of the soil and sediment samples $(<63 \mu \mathrm{m})$ was digested on water bath at $95{ }^{\circ} \mathrm{C}$ using aqua regia (HCl-HNO3; 3:1) for $2 \mathrm{~h}$ (Reis et al., 2007) and $\mathrm{HClO} 4$ for $1 \mathrm{~h}$. After digestion, all samples were filtered through S\&S ME24 $(0.2 \mu \mathrm{m})$ filter paper and replenished to $50 \mathrm{ml}$ with de-ionized water, and stored in sterile polythene tubes prior to analysis. The solutions were analysed by ICP-OES (GBC Integra) for $\mathrm{Al}, \mathrm{B}, \mathrm{Ba}, \mathrm{Be}, \mathrm{Bi}, \mathrm{Ca}, \mathrm{Cd}, \mathrm{Co}, \mathrm{Cr}, \mathrm{Cu}, \mathrm{Fe}, \mathrm{Ga}, \mathrm{K}, \mathrm{Li}, \mathrm{Mg}, \mathrm{Mn}, \mathrm{Mo}, \mathrm{Na}, \mathrm{Ni}, \mathrm{P}, \mathrm{Pb}, \mathrm{Se}, \mathrm{Sr}$, $\mathrm{Te}, \mathrm{Tl}$ and $\mathrm{Zn}$. In order to assess the validity of the analytical results, accuracy and precision (repeatability) were calculated. The results show that the accuracy of the analytical procedure was usually below $5.5 \%$, while the precision was less than $5 \%$ for all elements. Total $\mathrm{N}$ was determined by the Kjeldahl method (Rutherford et al., 2008) and the total organic C content was measured by the Walkley-Black method (Skjemstad and Baldock, 2008).

\subsection{Source discrimination}

A key requirement of any sediment source fingerprinting exercise is the use of statistical tests to identify a composite fingerprint or set of source material properties that is capable of discriminating between potential sources. In this study, a two stage procedure proposed by (Collins et al., 1997) was used to identify composite fingerprints capable of discriminating the samples collected to represent individual source types. In the first stage, the Kruskall-Wallis test was used to identify those fingerprint properties which were able to discriminate between the three potential sources. The Kruskall-Wallis test is a non-parametric alternative to one-way (between-groups) ANOVA. It is used to compare three or more samples, and it tests the null hypothesis that the different samples in the comparison were drawn from the same distribution or from distributions with the same median. Thus, the interpretation of the Kruskall-Wallis test is basically similar to that of the parametric one-way ANOVA, except that it is based on ranks rather than means (Sprent and Smeeton, 2001). 
In the second stage, a stepwise multivariate discriminant function analysis (DA) was undertaken, in order to select the optimum combination of enzyme activities as biochemical tracers. The membership of the sediment source samples was the dependent variable, whereas the measured soil enzyme activities constituted the independent variables. There are different tests to determine whether discriminant functions are statistically significant. The eigenvalue reflects the ratio of importance of the dimensions which classify cases of the dependent variable. The largest eigenvalue corresponds to the eigenvector in the direction of the maximum spread of the groups' means. The canonical correlation $(\mathrm{R})$ is a measure of the association between the groups formed by the dependent variable and the given discriminant function. Values close to 1 indicate a strong correlation between the discriminant scores and the groups. Wilks' Lambda is used to test the significance of the discriminant function as a whole. Wilks' Lambda is the proportion of the total variance in the discriminant scores not explained by differences among the groups. A chi-square transformation of Wilks' Lambda is used along with the degrees of freedom to determine its significance. Wilks' Lambda ranges between 0 and 1. Values close to 0 indicate the group means are different. If the associated probability is small (< 0.10) group means differ (Härdle and Simar, 2007; Hill and Lewicki, 2007).

The squared Mahalanobis distance, which is the distance of a tracer property associated with each sample from the centroid in the multidimensional space defined by independent variables, was also used as auxiliary information to evaluate the capacity of the set of property variables to discriminate between the source groups. The Mahalanobis distance is similar to the squared Euclidean distance. However, unlike the Euclidean distance, the Mahalanobis distance takes into account the intercorrelations between the variables in the model. Therefore, this measure provides an indication of whether or not a tracer property associated with each sample is an outlier with respect to the potential sediment source values (Hill and Lewicki, 2007).

Standard, forward and backward stepwise DA was performed to find the best set of tracers. Three analyses were performed: one with biochemical tracers only, one with geochemical tracers only and one where all tracers were combined. All statistical analyses were performed using STATISTICA V.6.0 (StatSoft Inc., 2001).

\subsection{Sediment source mixing model}

The relative contributions of sediment from the two surface and the streambank sources were determined using a mixing model proposed by Collins et al. (1997). The model calculates the proportions contributed by the sources by minimising iteratively the sum of the squares of the relative errors:

$$
\sum_{i=1}^{n}\left\{\left(C_{i}-\left(\sum_{s=1}^{m} P_{s} S_{s i} Z_{s}\right)\right) / C_{i}\right\}^{2}
$$

where, $C i=$ concentration of fingerprint property $(i)$ in sediment sample; $P s=$ the optimised percentage contribution from source category $(s)$; Ssi = concentration of fingerprint property in source 
category $(s)$; $Z s=$ particle size correction factor for source category calculated as the ratio of the specific surface area of the sediment samples to the mean of the individual source types; $n=$ number of fingerprint properties; $m=$ number of sediment sources.

The equation established by Collins et al. (1997) includes corrections for particle size and organic matter (using organic carbon). It may be expected that the particle size correction factor $(Z s)$ shows the same trend as the organic matter correction factor. Therefore no additional correction was applied for the organic fractions/tracers.

The model is based on the following constraints: the fraction of source contributions must lie between

0 and $1\left(0 \leq P_{s} \leq 1\right)$; and the percentage source contributions must sum to $1\left(\sum_{i=1}^{n} P_{s}=1\right)$. The mixing model was implemented in MATLAB and the contribution of each source to the sediment samples was calculated.

\section{Results}

\subsection{Source discrimination}

An important consideration for sediment tracer studies is data variability within the sediment sources. Comparison of rangeland, orchard, and streambank sediment source data shows that orchards have a higher mean value for all soil enzymes data compared to rangelands and streambanks (Fig. 2). Soil enzyme activities are higher on agricultural land due to addition of carbon, nitrogen and phosphor sources from fertilizers and manure (Stark et al., 2007). It is therefore not unexpected that relatively strong correlations exist between SOC content and enzyme activity (Fig. 3). Correlations with other geochemical tracers were variable: $\mathrm{Tl}$ was positively correlated with all soil biochemical tracers $(r>0.32)$ and B was negatively correlated with alkaline phosphatase $(r=0.31)$. Sr was not correlated with other biochemical properties (Fig. 3).

Catchment characteristics (such as geological formation and soil types) could be controlling the variability of the enzyme activities in different sediment sources. The dependence of enzyme activities upon geological formation and soil types was statistically analyzed using ANOVA for sediment sources, separately. ANOVA tests the significant difference between means of each level (e.g., Typic Xerorthents versus Typic Calcixerepts for soil types). The ANOVA results are shown in Table 1. For rangeland, geological formation and soil type showed significance for alkaline phosphatase, $\beta$ glucosidase and dehydrogenase and were therefore included in the sediment source model (Table 1). For orchard sediment source model geological formation showed significance for alkaline phosphatase (Table 1). For the streambank samples, both geological formation and soil type showed significance for dehydrogenase and were therefore included in the sediment source model (Table 1).

One-way ANOVA using Tukey unequal N HSD Post Hoc tests (unequal samples sizes) were performed to test the significance of the difference in mean values of the enzyme activities within different sediment sources (interaction). All enzyme means for the three sediment sources were 
significantly different except for the difference between alkaline phosphatase and urease values for rangeland and streambank sediment sources (Table 2). Results for the Kruskal-Wallis test are presented in Table 3 and indicate that all four enzyme activities showed a statistically significant difference between the sources. These results demonstrate that the enzyme activities have significant contrasts between sediment sources under catchment characteristics and are promising to be diagnostic properties for the fingerprinting techniques.

DA was done with the three sediment sources as grouping variable and the 4 enzymes as independent variables. A highly significant result was obtained, independent of the discriminant function removal method used (Table 4). Wilk's Lambda values indicate that $85-86 \%$ of the total variance is explained by differences between groups. Thus, the set of enzymes used clearly allow discriminating between the three potential sediment sources.

The Mahalanobis distance shows that the rangeland and streambank source groups are the most similar in terms of their composite fingerprints (Table 5). However, the distances between all sources are significantly different. F-values of the backward mode are significantly higher as compared to standard and forward mode.

The standard and forward stepwise discriminant analysis mode yielded classification matrices assigning ca. 95\% of the cases correctly (Tables 6 and 8). However, in the backward stepwise mode, $95.2 \%$ of the sediment sources were correctly classified by a model using only two discriminant parameters, $\beta$-glucosidase and dehydrogenase (Tables 6 and 8).

DA was also done with the three sediment sources as grouping variable and the 18 geochemical tracers remaining after the Kruskall-Wallis test (Table 3) as independent variables. The results of Chi-Square tests and Mahalanobis distance were shown in Tables 4 and 5. The backward DA stepwise mode showed that $92.9 \%$ of the sediment sources were correctly classified by a model using 4 discriminant parameters, boron, B, carbon, C, strontium, $\mathrm{Sr}$ and thallium, Tl (Tables 6 and 8).

Furthermore DA was done with the three sediment sources as grouping variable and the 22 enzymes and geochemical tracers as independent variables. The Chi-Square tests and Mahalanobis distance results were shown in Tables 4 and 5. The backward DA stepwise mode showed that $100 \%$ of the sediment sources were correctly classified by a model using 6 discriminant parameters, dehydrogenase, boron, B, carbon, C, beryllium, Be, cobalt, Co, and thallium, Tl (Tables 7 and 8).

\subsection{Sediment source contribution}

The mixing model was set up using only the enzymes retained by backward DA. Using $\beta$-glucosidase and dehydrogenase as sediment tracers the mean relative contributions (average \pm SE) from rangeland, orchard and streambank sources was calculated as $11.3 \pm 6.3 \%, 15.1 \pm 6.2 \%$ and $73.7 \pm 9.1 \%$, respectively (Table 9).

The mean contribution from rangeland, orchard and streambank sources was estimated $14.1 \pm 5.6 \%$, $9.5 \pm 4.1 \%$ and $74.8 \pm 6.4 \%$, respectively, using the geochemical tracers boron, B, carbon, $\mathrm{C}$, strontium, 
$\mathrm{Sr}$ and thallium, $\mathrm{Tl}$ which were selected using backward DA (Table 9). In addition, the results of using the combined biochemical and geochemical tracers dehydrogenase, boron, B, carbon, C, beryllium, $\mathrm{Be}$, cobalt, $\mathrm{Co}$, and thallium, $\mathrm{Tl}$ showed that the mean contribution from rangeland, orchard and streambank sources was $18.7 \pm 6.6 \%, 10.7 \pm 4.6 \%$ and $70.7 \pm 8.2 \%$, respectively (Table 9 ). The results of mixing model based on the best subset of composite biochemical fingerprints ( $\beta$-glucosidase and dehydrogenase), have been plotted on the study area (Fig. 5).

Comparison of relative contribution of each source for each of the sediment samples as calculated from geochemical and biochemical tracer analysis showed that for individual samples the calculated sediment source partitioning differed often considerably, depending on the tracer type used: the root mean square difference is below $25 \%$ for $50 \%$ of the samples but can be as high as $48 \%$ (Table 9). Except for one case the very high root mean square difference values are all associated with a higher estimated contribution of the streambanks to the deposited sediment when enzymes are used. Two reasons may cause this. First, it is possible that this might be caused by the fact that enzyme activity in the sediment samples has evolved after sediment deposition thereby becoming more similar in pattern to what is found on the river banks. This is unlikely: the sediment samples were collected from the upper layer of sediment which was deposited during recent events. Furthermore, the environmental conditions in sediment stores and streambanks are very different. Once particulate organic substrates have been deposited behind check dams, the anoxic conditions and low temperatures reduce microbial activities thereby favoring enzyme preservation. Alternatively, this finding may indicate that some of the sediment found in the deposition areas has the rangelands as its primary sources, but has resided for a relatively long time period within the streambank, so that the signal picked up by the biochemical tracers is no longer that of the primary sediment source, but that of the secondary reservoir. Samples 5 and 11 were taken in stream section crossing an orchard zone: the biochemical markers indicate a strong contribution from the orchards, while the geochemical markers point to a streambank origin of the sediment (Fig. 5). The biochemical markers pick up the signal present in the organic fraction, which may indeed be different from the signal present in the mineralogical fraction. The signal in the organic fraction may be strongly affected by a local source if the latter provides a relatively low amount of sediment that is strongly enriched in organic carbon. The root mean square difference between the results from the composite biogeochemical and the results from geochemical tracers only is lower than the difference between the composite biogeochemical tracers and the biochemical tracers only (Table 9).

\section{Discussion}

Our results indicate that soil enzymes are promising tools for sediment fingerprinting. They allow for a meaningful separation of sediment sources which appears to be preserved in the mixed samples found in sediment deposits. Two factors are key:

- Enzymes do indeed allow to discriminate between different sediment sources. This discrimination is 
undoubtedly to a large extent due to human impact: fertilization and management lead to increased SOC content having a very important effect on enzyme activity. A distinction between streambanks and rangelands is also possible: this is probably related to the variation of soil microbial activity with depth. Soil microbial activity at the surface (on the rangeland) is generally higher than soil microbial activity at depth in a streambank. The generally lower soil microbial activity in streambanks causes a decrease in enzyme activities. Hence enzyme activity is significantly lower in streambank sediments compared to other sources.

- Enzymes are products of microbial activity that may show important temporal dynamics. However, several recent studies indicate that the activity of enzymes in a soil environment is often relatively stable (Nannipieri et al., 2002; Tabatabai and Dick, 2002; Tate, 2002). The soil environment within which the enzyme activities occur is a complex array of sand, silt, and clay particles intermixed with a diverse array of organic substances. The adsorption of enzymes on clay and/or humic substances and the mineral phase of soil has important consequences not only for their mobility and stabilization (Tate, 2002), but also for their detachment and movement by water during the erosion process. Organic matter in soils protects enzymes against microbial degradation. Numerous studies have shown that enzyme activities are significantly correlated with organic $\mathrm{C}$ in surface soils and soil profiles (e.g. Chaer et al., 2009). Therefore it is generally accepted that enzymes in soils are immobilized within a network of organomineral complexes (Tabatabai and Dick, 2002) that can persist for extended periods of time and have a very important role in the biogeochemical cycles of major elements $(\mathrm{C}, \mathrm{N}, \mathrm{P}$, and $\mathrm{S}$; Killham and Staddon, 2002). Enzymes appear therefore to be sufficiently stable to be used as sediment tracers provide that fresh sediment samples are used. Clearly this needs further confirmation through specifically designed experiments.

\section{Conclusions}

Soil enzymes were hitherto only rarely used to discriminate between sediment sources. Our results obtained from an experimental area in Iran indicate that, nevertheless, the use of enzymes has a potential to complement existing methods to identify sediment sources. Enzyme activity under different land uses/landscape settings is indeed sufficiently different to allow for discrimination. Using enzymes we obtained a sediment source discrimination that was generally similar to the one we obtained from geochemical tracers but some important differences were identified.

Biochemical tracers may provide complementary information to geochemical tracers. While the former will give an indication of the primary sources of sediment enzymes may provide valuable additional information about the residence time of sediments within the system, thereby allowing a further differentiation and a better understanding of the system. However, there are some factors that enhance the uncertainty of the results from the individual enzyme activities such as the lack of reliable quantitative information on how enzyme activity varies with the specific-surface-area of soil particles and affect enzyme activity and preservation. 
Evidently, a major concern is the stability of enzymes when they are moved from one environment to another. Recent literature indicates that enzymes are indeed stable over extended periods of time: this may especially be true in depositional environments due to the lack of oxygen and the relatively low temperatures. However, quantitative information on the length of this "extended" time period is still absent: further research should on enzyme stability would therefore be of great help to define the conditions under which enzyme activity may be successfully used as a sediment tracer.

\section{Acknowledgements}

The authors gratefully acknowledge the Forest, Range and Watershed Management Organization, Tehran, Iran for financial support. We also thank Engineer P. Garshasebi for assisting us with field work and Mr. A. Abbasi for assisting us with laboratory studies at Faculty of Biology, University of Tehran. Matthias Vanmaercke received a PhD-scholarship from the Research Foundation - Flanders (FWO), Belgium.

\section{References}

Acosta-Martinez V. and Zobeck T. M. 2004, Enzyme activities and arylsulfatase protein content of dust and the soil source: biochemical fingerprints? Journal of Environmental Quality, Vol. 33, pp. 1653-1661.

Alef K. and Nannipieri P. 1995, Urease activity. In: Alef K. and Nannipieri P. (Eds) Methods in Applied Soil Microbiology and Biochemistry. Academic Press, Inc., San Diego, CA, pp. 316320.

Chaer G. M., Myrold D. D., and Bottomley P. J. 2009, A soil quality index based on the equilibrium between soil organic matter and biochemical properties of undisturbed coniferous forest soils of the Pacific Northwest. Soil Biology \& Biochemistry, Vol. 41, pp. 822-830.

Collins A. L., Walling D. E., and Leeks G. J. L. 1997, Source type ascription for fluvial suspended sediment based on a quantitative composite fingerprinting technique. Catena, Vol. 29, No. 1, pp. 1-27.

Collins A. L., Walling D. E., and Leeks G. J. L. 1998, Use of composite fingerprints to determine the provenance of the contemporary suspended sediment loads transported by rivers. Earth Surface Processes and Landforms, Vol. 23, pp. 31-52.

Estrany J., Garcia C., and Walling D. E. 2010, An investigation of soil erosion and redistribution in a Mediterranean lowland agricultural catchment using caesium-137. International Journal of Sediment Research, Vol. 25, pp. 1-16.

Foster I. D. L. and Walling D. E. 1994, Using reservoir deposits to reconstruct changing sediment yields and sources in the catchment of the Old Mill Reservoir, South Devon, UK, over the past 50 years. Hydrological Sciences Journal, Vol. 39, pp. 347-368.

Fox J. F. and Papanicolaou A. N. 2008, Application of the spatial distribution of nitrogen stable isotopes for sediment tracing at the watershed scale. Journal of Hydrology, Vol. 358, No. 1-2, pp. 46-55.

Härdle W. and Simar L. 2007, Applied Multivariate Statistical Analysis. Second Edition SpringerVerlag Berlin

Heidelberg. Hatfield R. G. and Maher B. A. 2009, Fingerprinting upland sediment sources: particle size-specific magnetic linkages between soils, lake sediments and suspended sediments. Earth Surface Processes and Landforms, Vol. 34, pp. 1359-1373.

Hill T. and Lewicki P. 2007, STATISTICS Methods and Applications. StatSoft, Tulsa, OK.

Juracek K. E. and Ziegler A. C. 2009, Estimation of sediment sources using selected chemical tracers in the Perry lake basin, Kansas, USA. International Journal of Sediment Research, Vol. 24, pp. $108-125$. 
Kandeler E. and Gerber H. 1988, Short-term assay of soil urease activity using colorimetric determination of ammonium. Biology and Fertility of Soils, Vol. 6, pp. 68-72.

Killham K. and Staddon W. J. 2002, Bioindicators and sensors of soil health and the application of geostatistics. In: Burns R. G. and Dick R. P. (Eds.), Enzymes in the Environment: Activity, Ecology and Applications. Marcel Dekker, Inc., New York, pp. 391-405.

Nannipieri P., Kandeler E., and Ruggiero P. 2002, Enzyme activities and microbiological and biochemical processes in soil. In: Burns R. G. and Dick R. P. (Eds.), Enzymes in the Environment: Activity, Ecology and Applications. Marcel Dekker, Inc., New York, pp. 1-33.

Naseby D. C. and Lynch J. M. 2002, Enzymes and microorganisms in the rhizosphere. In: Burns R. G. and Dick R. P. (Eds.), Enzymes in the Environment: Activity, Ecology and Applications. Marcel Dekker, Inc., New York, pp. 109-123.

Nosrati K. 2010, Impact of erosion on the variation of some soil physico-chemical and biological properties. PhD thesis, Faculty of Natural Resources, University of Tehran.

Nosrati K., Feiznia F., Van Den Eeckhaut M., and Duiker S.W. 2011. Assessment of soil erodibility in Taleghan Drainage Basin, Iran using multivariate statistics. Physical Geography, Vol. 32, No. 1, pp. 78-96.

Poulenard J., Perrette Y., Fanget B., Quetin P., Trevisan D., and Dorioz J. M. 2009, Infrared spectroscopy tracing of sediment sources in a small rural watershed (French Alps). Science of the Total Environment, Vol. 407, No. 8, pp. 2808-2819.

Reis A. P., Menezes de Almeida L., Ferreira da Silva E., Sousa A. J., Patinha C., and Fonseca E. C. 2007, Assessing the geochemical inherent quality of natural soils in the Douro river basin for grapevine cultivation using data analysis and geostatistics. Geoderma, Vol. 141, pp. 370-383.

Rowan J. S., Goodwill P., and Franks S. W. 2000, Uncertainty estimation in fingerprinting suspended sediment sources. In: Foster I. D. L. (Ed.), Tracers in Geomorphology. Wiley, Chichester, UK, pp. 279-290.

Rutherford P. M., McGill W. B., Arocena J. M., and Figueiredo C. T. 2008, Total nitrogen. In: Carter M. R. and Gregorich E. G. (Eds.), Soil Sampling and Methods of Analysis, Second Edition, CRC Press, Taylor \& Francis Group, Boca Raton, pp. 225-237.

Skjemstad J. O. and Baldock J. A. 2008, Total and organic carbon. In: Carter M. R. and Gregorich E. G. (Eds.), Soil Sampling and Methods of Analysis, Second Edition, CRC Press, Taylor \& Francis Group, Boca Raton, pp. 225-237.

Smith H. G. and Dragovich D. 2008, Improving precision in sediment source and erosion process distinction in an upland catchment, south-eastern Australia. Catena, Vol. 72, No. 1, pp. 191203.

Sprent P. and Smeeton N. C. 2001, Applied Nonparametric Statistical Methods. Third Edition, CRC Press LLC, Boca Raton, Florida.

Stark C., Condron L. M., Stewart A., Di H. J., and O'Callaghan M. 2007, Effects of past and current crop management on soil microbial biomass and activity. Biology and Fertility of Soils, Vol. 43 , pp. 531-540.

StatSoft Inc. 2001, STATISTICA: [data analysis software system], Version 6.0 for Windows update. StatSoft, Inc. Tabatabai M. A. 1994, Soil enzymes. In: Weaver R. W., Angle J. S. and Bottomley P. J. (Eds.), Methods of Soil Analysis. Part 2, Microbiological and Biochemical Properties. SSSA, Madison, pp. 775-833.

Tabatabai M. A. and Dick W. A. 2002, Enzymes in soil research and developments in measuring activities. In: Burns R. G. and Dick R. P. (Eds.), Enzymes in the Environment: Activity, Ecology and Applications. Marcel Dekker, Inc.,New York, pp. 567-596.

Tate III A. L. 2002, Microbiology and enzymology of carbon and nitrogen cycling. In: Burns R. G. and Dick R. P. (Eds.), Enzymes in the Environment: Activity, Ecology and Applications. Marcel Dekker, Inc., New York, pp. 227-248.

Walling D. E., Collins A. L., and Sichingabula H. M. 2003, Using unsupported lead-210 measurements to investigate soil erosion and sediment delivery in a small Zambian catchment. Geomorphology, Vol. 52, No. 3-4, pp. 193-213.

Yi Y., Wang Z., Zhang K., Yu G., and Duan X. 2008, Sediment pollution and its effect on fish through food chain in the Yangtze River. International Journal of Sediment Research, Vol. 23, pp. $338-347$. 
Zhang Q., Lei T., and Zhao J. 2008, Estimation of the detachment rate in eroding rills in flume experiments using an REE tracing method. Geoderma, Vol. 147, No. 1-2, pp. 8-15.

Zornoza R., Mataix-Solera J., Guerrero C., Arcenegui V., García-Orenes F., Mataix-Beneyto J., and Morugán A. 2007, Evaluation of soil quality using multiple lineal regression based on physical, chemical and biochemical properties. Science of the Total Environment, Vol. 378, pp. 233-237. 


\section{FIGURES}
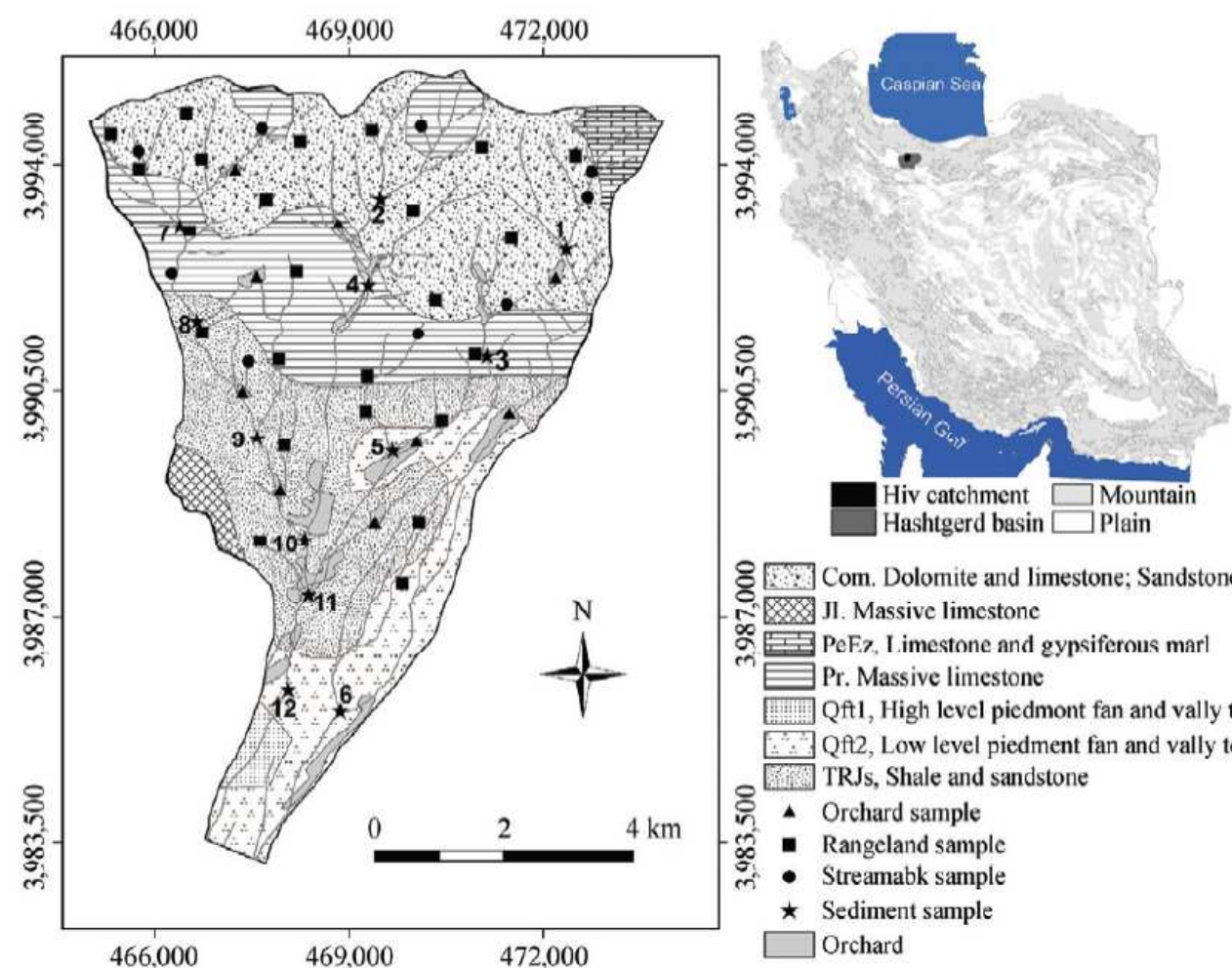

8 C. Com. Dolomite and limestone; Sandstone and shale Jl. Massive limestone

돌 PeFr, Limestone and gypsiferous mar

लPr. Massive limestone

-inte Qft, High level piedmont fan and vally terrace deposits

$\therefore$ Qft2, Low level piedment fan and vally terrace dposits

[inds, Shale and sandstone

\& $\triangle$ Orchard sample

- Rangeland sample

- Streamabk sample

$\star$ Sediment sample

$\square$ Orchard

Fig. 1 Location map and geological formations map of the Hiv catchment and sampling sites used in this analysis
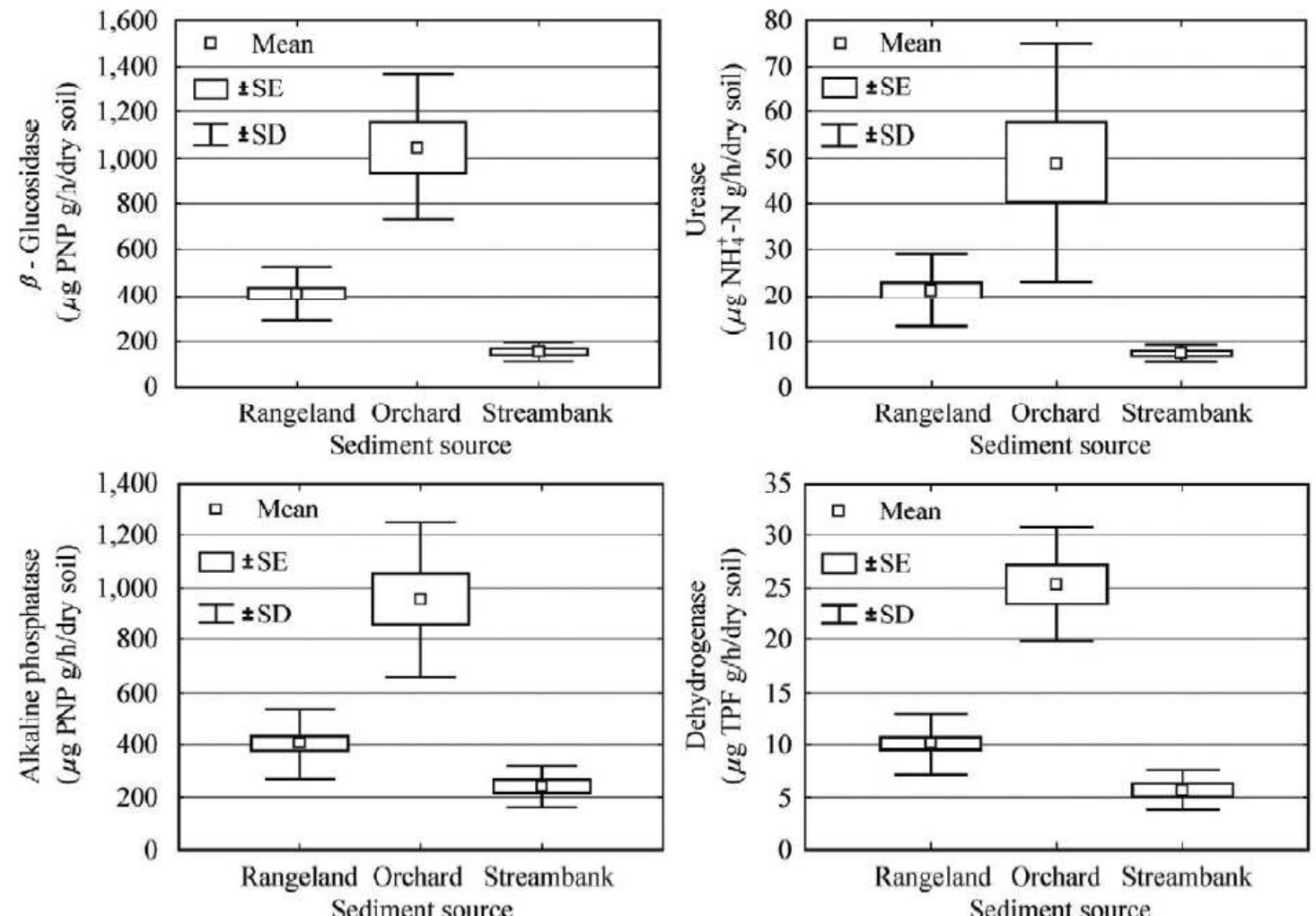

Fig. 2 Box and whisker plots of enzyme activities in different sediment sources of the Hiv catchment; SE, standard error; SD, standard deviation 


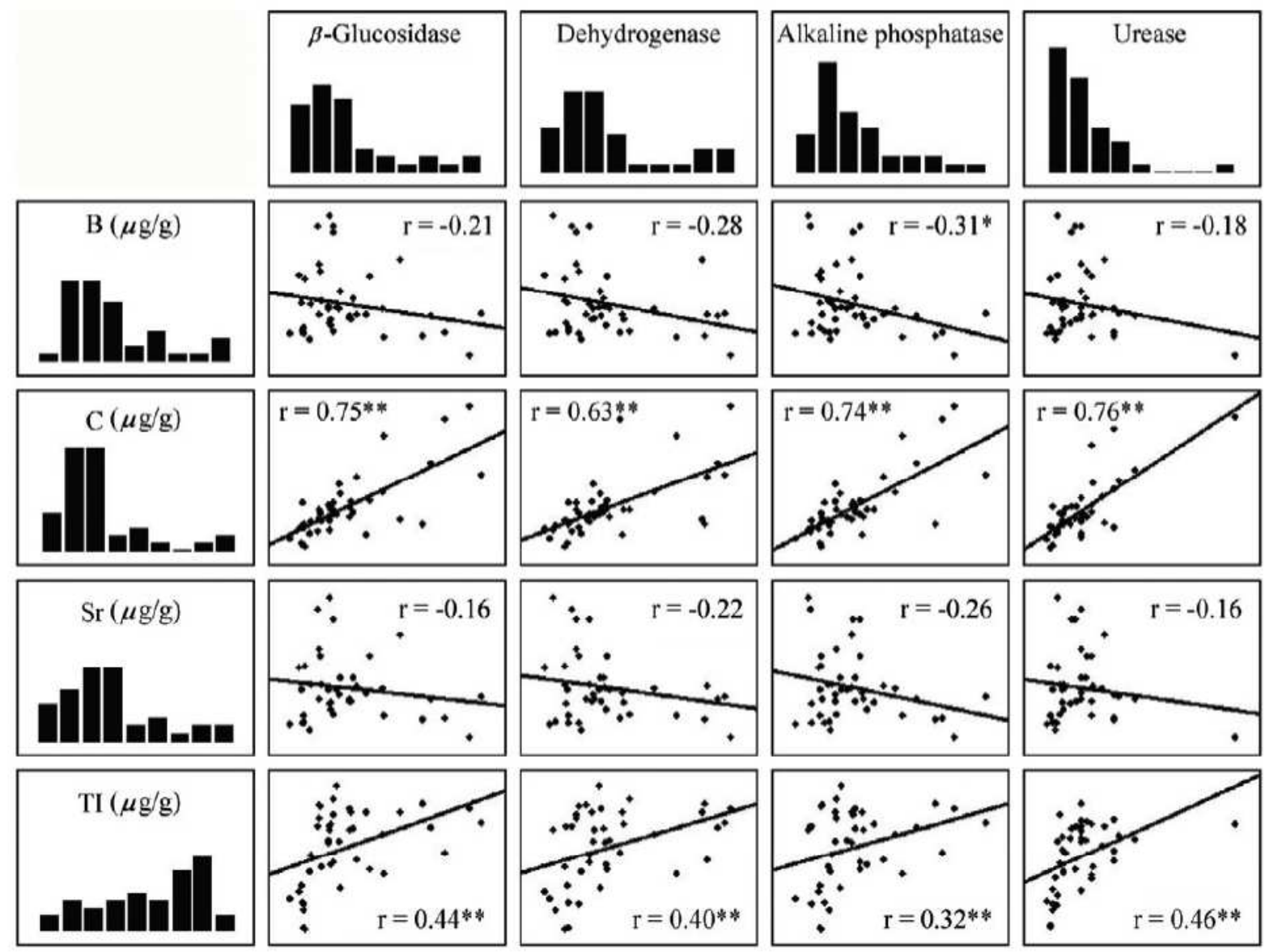

Fig. 3 Scatterplot matrix of the biochemical and geochemical properties used in sediment fingerprinting in Hiv catchment; $(* *)$ correlation is significant at the 0.01 level and $\left(^{*}\right)$ correlation is significant at the 0.05 level
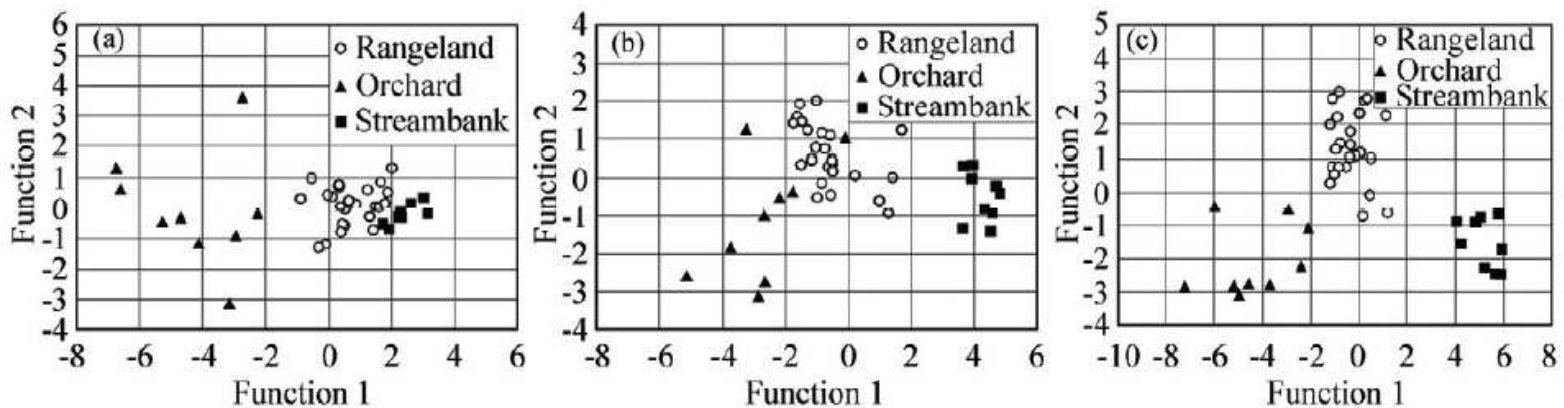

Fig. 4 Scatterplot of the first and second discriminant functions calculated using backward DA associated with selection of the optimum composite (a) biochemical tracers ( $\beta$-glucosidase and dehydrogenase), (b) geochemical tracers (B, C, Sr and Tl), and (c) combined biochemical and geochemical tracers (dehydrogenase, B, Be, C, Co and Tl) for the Hiv catchment 


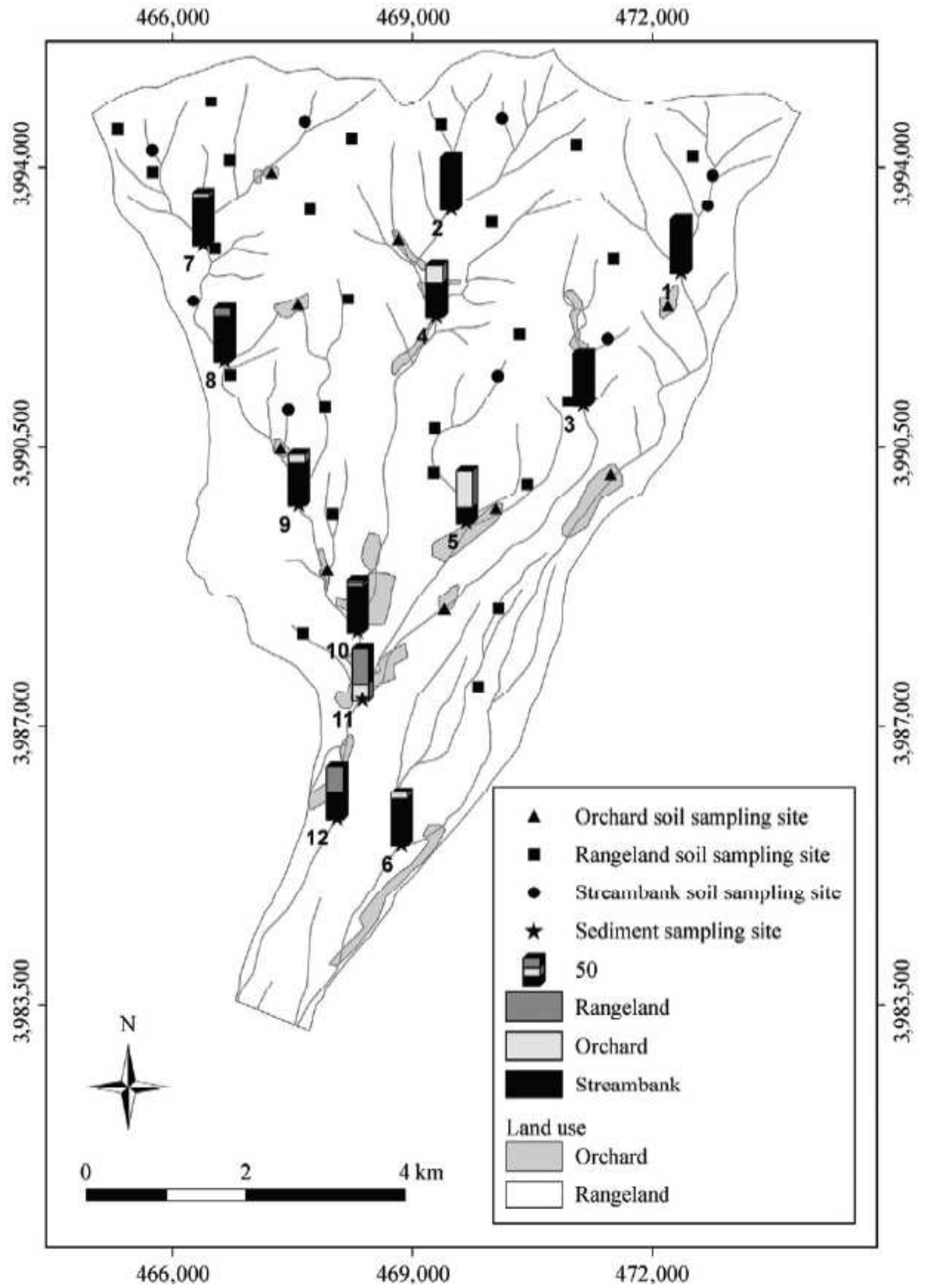

Fig. 5 Relative contribution of sediment stacked bars based on the biochemical tracers plotted on the study area 


\section{TABLES}

Table 1 ANOVA models for enzyme activities for sediment sources

\begin{tabular}{|c|c|c|c|c|c|c|c|c|c|c|c|c|c|}
\hline \multirow{3}{*}{$\begin{array}{l}\text { Sediment } \\
\text { source }\end{array}$} & \multirow{3}{*}{$\begin{array}{c}\text { Catchment } \\
\text { charac- } \\
\text { teristic }\end{array}$} & \multicolumn{12}{|c|}{ Enzyme activities } \\
\hline & & \multicolumn{3}{|c|}{$\beta$-Glucosidase } & \multicolumn{3}{|c|}{ Dehydrogenase } & \multicolumn{3}{|c|}{ Alkaline phosphatase } & \multicolumn{3}{|c|}{ Urease } \\
\hline & & \begin{tabular}{|c} 
Adjusted \\
$R^{2}$
\end{tabular} & F-value & $P$-value & \begin{tabular}{|c|} 
Adjusted \\
$R^{2}$ \\
\end{tabular} & F-value & P-value & \begin{tabular}{|c|} 
Adjusted \\
$\mathrm{R}^{2}$ \\
\end{tabular} & F-value & P-value & \begin{tabular}{|c|} 
Adjusted \\
$R^{2}$ \\
\end{tabular} & F-value & P-value \\
\hline \multirow{2}{*}{$\begin{array}{l}\text { Range- } \\
\text { land }\end{array}$} & $\begin{array}{l}\text { Geological } \\
\text { formation }\end{array}$ & - & - & ns & 0.29 & 5.68 & $0.01 *$ & - & - & ns & - & - & ns \\
\hline & Soil type & 0.13 & 4.85 & $0.04 *$ & - & - & ns & 0.16 & 5.25 & $0.03 *$ & - & - & ns \\
\hline \multirow[t]{2}{*}{ Orchard } & $\begin{array}{l}\text { Geological } \\
\text { formation }\end{array}$ & - & - & ns & - & - & ns & 0.40 & 5.01 & $0.03 *$ & - & - & ns \\
\hline & Soil type & - & - & ns & - & - & ns & - & - & ns & - & - & ns \\
\hline \multirow{2}{*}{$\begin{array}{l}\text { Stream- } \\
\text { bank }\end{array}$} & $\begin{array}{l}\text { Geological } \\
\text { formation }\end{array}$ & - & - & ns & 0.51 & 6.63 & $0.02 *$ & - & - & ns & - & - & ns \\
\hline & Soil type & - & - & ns & 0.48 & 11.26 & $0.01 *$ & - & - & ns & - & - & ns \\
\hline
\end{tabular}

* Statistically significant $(\mathrm{p}$-value $=0.05)$.

ns - Not significant.

Table 2 p-value of one-way ANOVA using Tukey unequal N HSD that comparedthe enzyme activities within different sediment sources

\begin{tabular}{|c|c|c|c|c|}
\hline \multirow[b]{2}{*}{ Source of variation } & \multicolumn{4}{|c|}{ Enzyme activities } \\
\hline & $\begin{array}{c}\beta \text {-Glucosidase } \\
\left(\mu \mathrm{g} \mathrm{PNP} \mathrm{g}^{-1} \mathrm{~h}^{-1} \text { dry soil) }\right.\end{array}$ & $\begin{array}{l}\text { Dehydrogenase } \\
\left(\mu \mathrm{g} \mathrm{TPF} \mathrm{g} \mathrm{g}^{-1} \mathrm{~h}^{-1}\right. \\
\text { dry soil) }\end{array}$ & $\begin{array}{c}\text { Alkaline } \\
\text { phosphatase } \\
\left(\mu \mathrm{g} \mathrm{PNP} \mathrm{g}^{-1} \mathrm{~h}^{-1}\right. \\
\text { dry soil })\end{array}$ & $\begin{array}{c}\text { Urease } \\
\left(\mu \mathrm{g} N H_{4}^{+}-N\right. \\
\mathrm{g}^{-1} \mathrm{~h}^{-1} \text { dry soil) }\end{array}$ \\
\hline Rangeland $\times$ Orchard & $<0.001^{*}$ & $<0.001^{*}$ & $<0.001^{*}$ & $<0.001^{*}$ \\
\hline Rangeland $\times$ Streambank & $0.009 *$ & $0.026^{*}$ & 0.118 & 0.085 \\
\hline Orchard $\times$ Streambank & $<0.001 *$ & $<0.001 *$ & $<0.001^{*}$ & $<0.001^{*}$ \\
\hline
\end{tabular}

* Statistically significant $(\mathrm{p}$-value $=0.05)$ 
Table 3 The result of the Kruskall-Wallis $H$ test for the sediment source discrimination in Hiv catchment

\begin{tabular}{|c|c|c|}
\hline Tracer & Chi-square & P-value \\
\hline \multicolumn{3}{|l|}{ Biochemical tracer } \\
\hline$\beta$-Glucosidase ( $\mu$ g PNP g ${ }^{-1} h^{-1}$ dry soil) & 30.85 & $0.000^{*}$ \\
\hline Dehydrogenase ( $\mu \mathrm{g} \mathrm{TPF} \mathrm{g}^{-1} \mathrm{~h}^{-1}$ dry soil) & 24.53 & $0.000^{2}$ \\
\hline Alkaline phosphatase ( $\mu \mathrm{g}$ PNP g ${ }^{-1} \mathrm{~h}^{-1}$ dry soil) & 32.13 & $0.000^{*}$ \\
\hline Urease $\left(\mu \mathrm{g} N H_{4}^{+}-N \mathrm{~g}^{-1} \mathrm{~h}^{-1}\right.$ dry soil $)$ & 27.02 & $0.000^{*}$ \\
\hline \multicolumn{3}{|l|}{ Geochemical tracer $(\mu \mathrm{g} / \mathrm{g})$} \\
\hline $\mathrm{Al}$ & 18.16 & $0.000^{\text {* }}$ \\
\hline $\mathrm{B}$ & 7.82 & $0.020^{*}$ \\
\hline $\mathrm{Ba}$ & 9.48 & $0.009^{*}$ \\
\hline $\mathrm{Be}$ & 13.16 & $0.001^{*}$ \\
\hline $\mathrm{Bi}$ & 4.49 & 0.106 \\
\hline $\mathrm{C}$ & 17.58 & $0.000^{*}$ \\
\hline $\mathrm{Ca}$ & 3.18 & 0.204 \\
\hline $\mathrm{Cd}$ & 6.86 & 0.032 * \\
\hline $\mathrm{Co}$ & 8.51 & $0.014^{*}$ \\
\hline $\mathrm{Cr}$ & 2.99 & 0.225 \\
\hline $\mathrm{Cu}$ & 9.38 & $0.009^{*}$ \\
\hline $\mathrm{Fe}$ & 9.81 & $0.007^{*}$ \\
\hline $\mathrm{Ga}$ & 2.89 & 0.236 \\
\hline $\mathrm{K}$ & 5.50 & 0.064 \\
\hline $\mathrm{Li}$ & 5.37 & 0.068 \\
\hline $\mathrm{Mg}$ & 5.50 & 0.064 \\
\hline $\mathrm{Mn}$ & 19.70 & $0.000^{*}$ \\
\hline Mo & 17.19 & $0.000^{*}$ \\
\hline $\mathrm{N}$ & 14.03 & $0.001^{*}$ \\
\hline $\mathrm{Na}$ & 0.62 & 0.733 \\
\hline $\mathrm{Ni}$ & 3.93 & 0.140 \\
\hline $\mathrm{P}$ & 6.57 & $0.037^{*}$ \\
\hline $\mathrm{Pb}$ & 13.93 & $0.001^{*}$ \\
\hline $\mathrm{Se}$ & 1.65 & 0.437 \\
\hline $\mathrm{Sr}$ & 8.27 & $0.016^{*}$ \\
\hline $\mathrm{Te}$ & 8.54 & $0.014^{*}$ \\
\hline $\mathrm{Tl}$ & 19.89 & $0.000^{*}$ \\
\hline $\mathrm{Zn}$ & 10.66 & $0.005^{*}$ \\
\hline
\end{tabular}

* Critical P-value $=0.05$.

Table 4 Chi-Square tests with successive discriminant functions removed for discriminant analysis applied to three sediment sources of Hiv catchment

\begin{tabular}{|l|c|c|c|c|c|c|}
\hline $\begin{array}{l}\text { Discriminant functions } \\
\text { removal method }\end{array}$ & Largest eigenvalue & Canonical-R & $\begin{array}{c}\text { Wilks' } \\
\text { lambda }\end{array}$ & Chi-Square & df & P-value \\
\hline Biochemical tracer & \multicolumn{5}{|l|}{} \\
\hline Standard mode & 5.89 & 0.925 & 0.140 & 73.8 & 8 & $<0.001$ \\
\hline Forward mode & 5.85 & 0.924 & 0.141 & 74.4 & 6 & $<0.001$ \\
\hline Backward mode & 5.83 & 0.924 & 0.144 & 74.6 & 4 & $<0.001$ \\
\hline Geochemical tracer & 13.25 & 0.964 & 0.027 & 110.6 & 36 & $<0.001$ \\
\hline Standard mode & 11.48 & 0.959 & 0.035 & 112.2 & 24 & $<0.001$ \\
\hline Forward mode & 5.99 & 0.926 & 0.093 & 89.2 & 8 & $<0.001$ \\
\hline Backward mode & \multicolumn{7}{|l|}{} \\
\hline Biochemical and geochemical tracers & 0.976 & 0.009 & 134.5 & 44 & $<0.001$ \\
\hline Standard mode & 20.26 & 0.967 & 0.014 & 142.1 & 24 & $<0.001$ \\
\hline Forward mode & 14.42 & 0.956 & 0.024 & 136.2 & 12 & $<0.001$ \\
\hline
\end{tabular}


Table 5 Mahalanobis distance values from applied to the three sediment sources of Hiv catchment

\begin{tabular}{|l|c|c|c|c|c|c|c|}
\hline \multirow{2}{*}{ Stepwise DA } & \begin{tabular}{l} 
Rangeland $\times$ Orchard \\
\cline { 2 - 7 }
\end{tabular} & $\begin{array}{c}\text { Rahalanobis } \\
\text { distance }\end{array}$ & F-value & Mahalanobis distance & F-value & Mahalanobis distance & F-value \\
\hline Biochemical tracer \\
\hline Standard mode & 25.2 & 38.0 & 3.0 & 4.6 & 44.8 & 46.5 \\
\hline Forward mode & 24.9 & 51.5 & 3.1 & 6.3 & 44.5 & 63.4 \\
\hline Backward mode & 24.9 & 79.4 & 2.9 & 9.2 & 44.3 & 97.1 \\
\hline Geochemical tracer \\
\hline Standard mode & 12.6 & 2.6 & 64.2 & 13.2 & 96.3 & 13.6 \\
\hline Forward mode & 9.7 & 3.8 & 56.4 & 22.1 & 81.9 & 22.0 \\
\hline Backward mode & 7.4 & 11.2 & 24.0 & 36.3 & 48.3 & 50.1 \\
\hline Biochemical and geochemical tracers \\
\hline Standard mode & 44.7 & 6.1 & 77.2 & 10.6 & 171.1 & 16.2 \\
\hline Forward mode & 36.7 & 14.4 & 53.1 & 20.8 & 123.3 & 33.2 \\
\hline Backward mode & 27.7 & 26.4 & 38.3 & 36.5 & 91.1 & 59.6 \\
\hline
\end{tabular}

Table 6 Classification functions resulting from discriminant analysis applied to the three sediment sources of Hiv catchment

\begin{tabular}{|c|c|c|c|c|c|c|c|c|c|c|c|c|}
\hline \multirow[b]{2}{*}{ Tracer } & \multicolumn{4}{|c|}{ Standard mode } & \multicolumn{4}{|c|}{ Forward mode } & \multicolumn{4}{|c|}{ Backward mode } \\
\hline & $\begin{array}{l}\text { Range- } \\
\text { land }\end{array}$ & Orchard & \begin{tabular}{|c|}
$\begin{array}{c}\text { Stream- } \\
\text { bank }\end{array}$ \\
\end{tabular} & P-value & $\begin{array}{l}\text { Range- } \\
\text { land }\end{array}$ & Orchard & $\begin{array}{l}\text { Stream- } \\
\text { bank }\end{array}$ & P-value & $\begin{array}{l}\text { Range- } \\
\text { land }\end{array}$ & Orchard & $\begin{array}{l}\text { Strea- } \\
\text { mbank }\end{array}$ & $\mathrm{P}$-value \\
\hline Biochemical tracer & \multicolumn{4}{|c|}{$F=15.1, p<0.0001$} & \multicolumn{4}{|c|}{$\mathrm{F}=20.5, \mathrm{p}<0.0001$} & \multicolumn{4}{|c|}{$F=31.1, p<0.0001$} \\
\hline$\beta$-Glucosidase & -0.67 & 5.76 & -3.92 & 0.07 & -0.47 & 5.03 & -3.77 & 0.04 & -0.61 & 4.67 & -3.04 & 0.00 \\
\hline Dehydrogenase & -1.27 & 6.86 & -3.46 & 0.00 & -1.23 & 6.69 & -3.43 & 0.00 & -1.26 & 6.60 & -3.24 & 0.00 \\
\hline $\begin{array}{l}\text { Alkaline } \\
\text { phosphatase }\end{array}$ & -0.11 & -0.67 & 0.95 & 0.74 & -0.17 & -0.45 & 0.91 & 0.69 & & & & \\
\hline Urease & 0.22 & -0.73 & 0.15 & 0.81 & & & & & & & & \\
\hline Constant & -0.83 & -10.77 & -4.45 & & -0.81 & -10.69 & -4.44 & & -0.81 & -10.67 & -4.38 & \\
\hline Geochemical tracer & \multicolumn{4}{|c|}{$\mathrm{F}=6.3, \mathrm{p}<0.0000$} & \multicolumn{4}{|c|}{$F=10.1, p<0.0000$} & \multicolumn{4}{|c|}{$F=20.6, p<0.0000$} \\
\hline $\mathrm{Al}$ & 1.03 & -3.80 & 1.06 & 0.23 & 0.84 & -1.89 & -0.36 & 0.38 & & & & \\
\hline B & -21.08 & -61.63 & 117.84 & 0.00 & -18.68 & -43.78 & 93.60 & 0.00 & -3.09 & -22.70 & 30.95 & 0.00 \\
\hline $\mathrm{Ba}$ & 0.05 & 1.48 & -1.62 & 0.59 & & & & & & & & \\
\hline $\mathrm{Be}$ & 1.53 & 1.72 & -5.79 & 0.02 & 1.28 & 1.13 & -4.54 & 0.01 & & & & \\
\hline $\mathrm{C}$ & 1.21 & 5.32 & -8.54 & 0.02 & 0.50 & 4.33 & -5.65 & 0.00 & 0.25 & 4.35 & -5.03 & 0.00 \\
\hline $\mathrm{Cd}$ & -0.66 & -1.59 & 3.35 & 0.26 & -0.51 & -0.94 & 2.30 & 0.31 & & & & \\
\hline Co & 21.35 & 27.62 & -84.56 & 0.06 & 16.32 & 10.53 & -54.06 & 0.02 & & & & \\
\hline $\mathrm{Cu}$ & -1.34 & -0.46 & 4.05 & 0.27 & -1.18 & -1.21 & 4.37 & 0.15 & & & & \\
\hline $\mathrm{Fe}$ & 0.62 & -5.21 & 3.56 & 0.68 & & & & & & & & \\
\hline $\mathrm{Mn}$ & -0.93 & -3.61 & 6.08 & 0.33 & & & & & & & & \\
\hline Mo & 0.35 & -1.44 & 0.50 & 0.46 & & & & & & & & \\
\hline $\mathrm{N}$ & -0.82 & -0.91 & 3.11 & 0.50 & & & & & & & & \\
\hline $\mathrm{P}$ & -0.16 & -0.94 & 1.35 & 0.91 & 0.07 & 0.03 & -0.22 & 1.00 & & & & \\
\hline $\mathrm{Pb}$ & -0.30 & 0.20 & 0.60 & 0.86 & & & & & & & & \\
\hline $\mathrm{Sr}$ & -0.07 & 40.73 & -40.55 & 0.03 & 2.06 & 31.70 & -37.18 & 0.02 & 3.65 & 23.80 & -33.54 & 0.00 \\
\hline $\mathrm{Te}$ & 1.44 & 2.46 & -6.29 & 0.06 & 1.23 & 1.27 & -4.55 & 0.07 & & & & \\
\hline $\mathrm{Tl}$ & 3.06 & 5.93 & -14.10 & 0.00 & 2.56 & 3.99 & -10.83 & 0.00 & 1.14 & 2.28 & -5.32 & 0.00 \\
\hline $\mathrm{Zn}$ & -0.04 & 4.57 & -4.47 & 0.30 & 0.43 & 4.38 & -5.54 & 0.13 & & & & \\
\hline Constant & -1.87 & -8.54 & -23.28 & & -1.71 & -7.15 & -20.51 & & -0.89 & -5.79 & -10.55 & \\
\hline
\end{tabular}


Table 7 Classification functions resulting from discriminant analysis applied to the three sediment sources of Hiv catchment using combined biochemical and geochemical tracers

\begin{tabular}{|c|c|c|c|c|c|c|c|c|c|c|c|c|}
\hline \multirow[b]{2}{*}{$\begin{array}{l}\text { Biochemical and } \\
\text { geochemical tracer }\end{array}$} & \multicolumn{4}{|c|}{ Standard mode $\mathrm{F}=7.8, \mathrm{P}<0.0001$} & \multicolumn{4}{|c|}{ Forward mode $\mathrm{F}=17.1, \mathrm{P}<0.0001$} & \multicolumn{4}{|c|}{ Backward mode $\mathrm{F}=31, \mathrm{P}<0.0001$} \\
\hline & $\begin{array}{l}\text { Range- } \\
\text { land }\end{array}$ & Orchard & $\begin{array}{l}\text { Stream- } \\
\text { bank }\end{array}$ & P-value & $\begin{array}{l}\text { Range- } \\
\text { land }\end{array}$ & Orchard & $\begin{array}{l}\text { Stream- } \\
\text { bank }\end{array}$ & P-value & $\begin{array}{l}\text { Range- } \\
\text { land }\end{array}$ & Orchard & $\begin{array}{l}\text { Stream- } \\
\text { bank }\end{array}$ & P-value \\
\hline$\beta$-Glucosidase & -2.13 & 10.30 & -4.63 & 0.34 & -2.77 & 6.66 & 0.73 & 0.10 & & & & \\
\hline Dehydrogenase & -1.82 & 9.51 & -4.65 & 0.21 & -1.90 & 10.67 & -5.61 & 0.00 & -1.66 & 10.11 & -5.68 & 0.00 \\
\hline Alkaline phosphatase & 1.64 & -0.68 & -3.70 & 0.75 & 2.32 & -0.23 & -5.97 & 0.15 & & & & \\
\hline Urease & -0.10 & -4.08 & 4.35 & 0.63 & 0.17 & -3.69 & 3.22 & 0.37 & & & & \\
\hline $\mathrm{Al}$ & 1.22 & -4.14 & 0.88 & 0.60 & 1.56 & 0.26 & -4.42 & 0.18 & & & & \\
\hline $\mathrm{B}$ & -24.87 & -59.86 & 126.17 & 0.01 & -16.00 & -17.00 & 59.66 & 0.01 & -9.09 & -18.03 & 42.29 & 0.00 \\
\hline $\mathrm{Ba}$ & 0.00 & 1.82 & -1.82 & 0.80 & & & & & & & & \\
\hline $\mathrm{Be}$ & 1.39 & 3.10 & -6.80 & 0.03 & 0.86 & 1.20 & -3.48 & 0.04 & 0.93 & 1.06 & -3.55 & 0.00 \\
\hline $\mathrm{C}$ & 1.31 & 6.50 & -9.98 & 0.11 & 0.72 & 5.35 & -7.26 & 0.02 & 0.32 & 4.47 & -5.33 & 0.00 \\
\hline $\mathrm{Cd}$ & -0.42 & -3.34 & 4.47 & 0.23 & & & & & & & & \\
\hline $\mathrm{Co}$ & 22.02 & 38.92 & -97.65 & 0.12 & 15.43 & 20.10 & -61.26 & 0.01 & 9.42 & 20.64 & -45.75 & 0.00 \\
\hline $\mathrm{Cu}$ & -0.99 & -2.18 & 4.83 & 0.47 & & & & & & & & \\
\hline $\mathrm{Fe}$ & 1.56 & -12.17 & 7.99 & 0.53 & & & & & & & & \\
\hline $\mathrm{Mn}$ & -1.16 & -2.46 & 5.55 & 0.60 & & & & & & & & \\
\hline Mo & 0.14 & -0.17 & -0.20 & 0.98 & & & & & & & & \\
\hline $\mathrm{N}$ & -0.59 & -1.76 & 3.34 & 0.72 & & & & & & & & \\
\hline $\mathrm{P}$ & 0.22 & -1.94 & 1.35 & 0.89 & 0.32 & -0.25 & -0.59 & 0.93 & & & & \\
\hline $\mathrm{Pb}$ & -0.57 & 1.74 & -0.23 & 0.62 & -0.54 & 1.92 & -0.49 & 0.33 & & & & \\
\hline $\mathrm{Sr}$ & 1.40 & 38.48 & -42.21 & 0.45 & & & & & & & & \\
\hline $\mathrm{Te}$ & 1.26 & 2.73 & -6.08 & 0.28 & & & & & & & & \\
\hline $\mathrm{Tl}$ & 3.56 & 5.99 & -15.49 & 0.00 & 2.41 & 2.02 & -8.45 & 0.00 & 1.89 & 1.78 & -6.82 & 0.00 \\
\hline $\mathrm{Zn}$ & 0.45 & 2.71 & -3.92 & 0.85 & & & & & & & & \\
\hline Constant & -2.23 & -21.26 & -30.53 & & -1.85 & -16.91 & -21.59 & & -1.50 & -13.09 & -16.12 & \\
\hline
\end{tabular}

Table 8 Classification matrix resulting from discriminant analysis applied to the three sediment sources of Hiv catchment

\begin{tabular}{|c|c|c|c|c|c|c|c|c|c|c|c|c|}
\hline \multirow{3}{*}{ Sediment sources } & \multicolumn{3}{|c|}{$\%$ correct } & \multicolumn{9}{|c|}{ Sampling sites of sediment sources assigned by DA } \\
\hline & \multirow[b]{2}{*}{$\begin{array}{l}\text { Bio } \\
\text { tracer }\end{array}$} & \multirow[b]{2}{*}{$\begin{array}{l}\text { Geo } \\
\text { tracer }\end{array}$} & \multirow[b]{2}{*}{$\begin{array}{c}\text { Bio-geo } \\
\text { tracer }\end{array}$} & \multicolumn{3}{|c|}{ Biochemical tracer } & \multicolumn{3}{|c|}{ Geochemical tracer } & \multicolumn{3}{|c|}{ Bio and geochemical tracers } \\
\hline & & & & $\begin{array}{l}\text { Range- } \\
\text { land }\end{array}$ & Orchard & \begin{tabular}{|c|}
$\begin{array}{c}\text { Stream- } \\
\text { bank }\end{array}$ \\
\end{tabular} & $\begin{array}{l}\text { Range- } \\
\text { land }\end{array}$ & Orchard & $\begin{array}{c}\text { Stream- } \\
\text { bank }\end{array}$ & $\begin{array}{c}\text { Range- } \\
\text { land }\end{array}$ & Orchard & $\begin{array}{l}\text { Stream- } \\
\text { bank }\end{array}$ \\
\hline \multicolumn{13}{|l|}{ Standard mode } \\
\hline Rangeland & 100 & 100 & 100 & 24 & 0 & 0 & 24 & 0 & 0 & 24 & 0 & 0 \\
\hline Orchard & 100 & 88.9 & 100 & 0 & 9 & 0 & 1 & 8 & 0 & 0 & 9 & 0 \\
\hline Streambank & 77.8 & 100 & 100 & 2 & 0 & 7 & 0 & 0 & 9 & 0 & 0 & 9 \\
\hline Total & 95.2 & 97.6 & 100 & 26 & 9 & 7 & 25 & 8 & 9 & 24 & 9 & 9 \\
\hline \multicolumn{13}{|l|}{ Forward mode } \\
\hline Rangeland & 100 & 100 & 100 & 24 & 0 & 0 & 24 & 0 & 0 & 24 & 0 & 0 \\
\hline Orchard & 100 & 88.9 & 100 & 0 & 9 & 0 & 1 & 8 & 0 & 0 & 9 & 0 \\
\hline Streambank & 77.8 & 100 & 100 & 2 & 0 & 7 & 0 & 0 & 9 & 0 & 0 & 9 \\
\hline Total & 95.2 & 97.6 & 100 & 26 & 9 & 7 & 25 & 8 & 9 & 24 & 9 & 9 \\
\hline \multicolumn{13}{|l|}{ Backward mode } \\
\hline Rangeland & 100 & 100 & 100 & 24 & 0 & 0 & 24 & 0 & 0 & 24 & 0 & 0 \\
\hline Orchard & 100 & 66.7 & 100 & 0 & 9 & 0 & 3 & 6 & 0 & 0 & 9 & 0 \\
\hline Streambank & 77.8 & 100 & 100 & 2 & 0 & 7 & 0 & 0 & 9 & 0 & 0 & 9 \\
\hline Total & 95.2 & 92.9 & 100 & 26 & 9 & 7 & 27 & 6 & 9 & 24 & 9 & 9 \\
\hline
\end{tabular}


Table 9 relative contributions of the three sediment source groups to the sediment yield of individual sediment samples using individual biochemical and geochemical tracers as well as combined biochemical and geochemical tracers resulted from stepwise DA in Hiv catchment

\begin{tabular}{|c|c|c|c|c|c|c|c|c|c|c|c|c|}
\hline \multirow{3}{*}{$\begin{array}{l}\text { Sediment } \\
\text { sample }\end{array}$} & \multirow{2}{*}{\multicolumn{3}{|c|}{$\begin{array}{c}\text { Biochemical tracer }^{\prime} \\
\text { Relative sediment yield (\%) }\end{array}$}} & \multirow{2}{*}{\multicolumn{3}{|c|}{\begin{tabular}{|c|} 
Geochemical tracer $^{2}$ \\
Relative sediment yield (\%)
\end{tabular}}} & \multirow{3}{*}{$\begin{array}{c}\text { RMS }^{3} \\
\text { Difference } \\
\text { geo } \\
\text { vs. bio }\end{array}$} & \multirow{2}{*}{\multicolumn{3}{|c|}{$\begin{array}{l}\text { Bio and geochemical tracers } \\
\text { Relative sediment yield (\%) }\end{array}$}} & \multirow{3}{*}{\begin{tabular}{|c|} 
RMS \\
Difference \\
biogeo \\
vs. bio
\end{tabular}} & \multirow{3}{*}{$\begin{array}{c}\text { RMS } \\
\text { Difference } \\
\text { biogeo } \\
\text { vs. geo }\end{array}$} \\
\hline & & & & & & & & & & & & \\
\hline & $\begin{array}{c}\text { Range- } \\
\text { land }\end{array}$ & Orchard & $\begin{array}{l}\text { Stream- } \\
\text { bank }\end{array}$ & $\begin{array}{c}\begin{array}{c}\text { Range- } \\
\text { land }\end{array} \\
\end{array}$ & Orchard & $\begin{array}{l}\text { Stream- } \\
\text { bank }\end{array}$ & & $\begin{array}{l}\text { Range- } \\
\text { land }\end{array}$ & Orchard & $\begin{array}{c}\text { Stream- } \\
\text { bank }\end{array}$ & & \\
\hline 1 & 0 & 0 & 100 & \begin{tabular}{|l|}
0 \\
\end{tabular} & 0 & 100 & 0.0 & 10 & 0 & 90 & \begin{tabular}{|l|}
8.2 \\
\end{tabular} & 8.2 \\
\hline 2 & 0 & 0 & 100 & 0 & 0 & 100 & 0.0 & 17 & 0 & 83 & 13.9 & 13.9 \\
\hline 3 & 0 & 0 & 100 & 0 & 0 & 100 & 0.0 & 0 & 0 & 100 & 0.0 & 0.0 \\
\hline 4 & 0 & 32 & 68 & 32 & 26 & 42 & 24.1 & 28 & 45 & 27 & 29.6 & 14.2 \\
\hline 5 & 0 & 71 & 29 & 4 & 19 & 77 & 40.9 & 6 & 7 & 87 & 50.0 & 9.1 \\
\hline 6 & 0 & 12 & 88 & 45 & 0 & 55 & 33.0 & 53 & 8 & 39 & 41.7 & 11.3 \\
\hline 7 & 0 & 8 & 92 & 0 & 6 & 94 & 1.6 & 0 & 6 & 94 & 1.6 & 0.0 \\
\hline 8 & 16 & 0 & 84 & 6 & 4 & 90 & 7.1 & 6 & 1 & 93 & 7.8 & 2.4 \\
\hline 9 & 0 & 17 & 83 & 38 & 6 & 56 & 27.7 & 35 & 23 & 42 & 31.3 & 12.8 \\
\hline 10 & 5 & 6 & 89 & 44 & 0 & 56 & 29.7 & 69 & 0 & 31 & 50.0 & 20.4 \\
\hline 11 & 65 & 35 & 0 & 0 & 47 & 53 & 48.9 & 0 & 38 & 62 & 51.9 & 7.3 \\
\hline 12 & 49 & 0 & 51 & 0 & 6 & 94 & 37.8 & 0 & 0 & 100 & 40.0 & 4.9 \\
\hline Mean & 11.3 & 15.1 & 73.7 & 14.1 & 9.5 & 74.8 & & 18.7 & 10.7 & 70.7 & & \\
\hline $\mathrm{SE}^{5}$ & 6.3 & 6.2 & 9.1 & 5.6 & 4.1 & 6.4 & & 6.6 & 4.6 & 8.2 & & \\
\hline
\end{tabular}

Biochemical tracers including: $\beta$-glucosidase and dehydrogenase.

${ }^{2}$ Geochemical tracers including: boron, B; carbon, C; strontium, $\mathrm{Sr}$; and thallium, Tl.

${ }^{3}$ RMS - Root mean square.

${ }^{4}$ Bio and geochemical tracers including: dehydrogenase, boron, B; carbon, C; beryllium, Be; cobalt, Co, and thallium. T1.

${ }^{5} \mathrm{SE}$ - standard error. 